\title{
Perception of Awon Mass Wedding Festival by Contemporary Shao Community of Kwara State, Nigeria
}

T. G. Yusuf $\mathrm{f}^{\mathrm{a}}$, Toluwalase M. Ikusemiju ${ }^{\mathrm{b}}$, A. S. Habeeb ${ }^{\mathrm{c}}$

${ }^{a}$ Obafemi Awolowo University, Ile - Ife, Nigeria.

${ }^{b}$ Federal Polytechnic, Ede, Osun State, Nigeria.

${ }^{c}$ The Federal Polytechnic, Bida, Niger State, Nigeria.

\section{ARTICLE INFO}

Keywords:

Perception

Shao Community

Awon

Mass Wedding Festival

\begin{abstract}
The study investigated the perception of Awon Mass Wedding Festival by the contemporary Shao community of Kwara State, Nigeria. The importance of this study dwells on reawakening the consciousness of relevant stakeholders towards ensuring sustainable development of Awon Mass Wedding Festival. Literature reveals that festivals are expressive ways to celebrate glorious heritage, culture, and traditions. Often, debates polarize into those advocating change and those wishing to preserve "traditional" or "local" culture in the face of modernization and globalization. However, preserving a culture ensures "authenticity" which is mostly cherished in heritage tourism. Awon Mass Wedding Festival is a unique culture found in very few countries of the world. Questionnaire was used to retrieve data from 20 maidens purposively selected and 107 residents selected by simple random technique. Participant observation and Key Informant Interview were also deployed to elicit information from respondents. The study established the most important factors encouraging maidens' participation to include culture $(54.2 \%)$ and family custom and tradition (19.6\%) while factors discouraging participation were; civilization (36.4\%), religion (17.7\%), lack of interest $(5.6 \%)$, educational level $(3.7 \%)$, erroneous belief about implications of participation in the festival (2.8\%), and emigration (1.9\%).Ways of improving the festival identified in this study were; increasing awareness and publicity (43\%), securing sponsorship (38.3\%), encouraging participation (14.9\%) and including more leisure activities in the festival (3.7\%). Correlation analysis showed a significant relationship between education $(\mathrm{r}=$ -0.194), membership of social organizations $(r=0.304)$ and perception of Awon festival at $\mathrm{p}<0.05$. Conclusively, majority of the community members have a positive perception of the festival, though this had been grossly influenced by religion. Contemporarily, not all maidens of the community subscribe to the festival unlike in the past. The study recommended that; members of the community should be re - orientated to support the festival, maidens of high social status should be encouraged to participate, and the Local Organizing Committee should strategize for better branding of the festival.
\end{abstract}

C2020 Faculty of Tourism and Hotels, Fayoum University All rights reserved

\footnotetext{
${ }^{*}$ Corresponding author, email: tajudeen.yusuf@yahoo.com
} 


\section{Introduction}

A festival is an event, usually and ordinarily staged by a community. It usually centers on and celebrates some unique aspects of a community. Often, the debates polarize into those advocating change and those wishing to preserve "traditional" or "local" culture in the face of modernization and globalization (Montserrat, 2007). Festivals are expressive ways to celebrate glorious heritage, culture, and traditions. Festivals are the most potent pulling forces that attracts tourists to destinations to participate in cultural tourism. Culture is the vehicle through which knowledge, beliefs, arts, morals, laws, customs and any other capabilities and habits are transmitted to members of a community from generation to generation (Bello, 2001). In overall and universally, all festivals are related to harmony, peace, and happiness (Hat Tours, 2012). Many participants of festivals are cultural tourists. Cultural tourism is the subset of tourism concerned with a country or region's culture, specifically the lifestyle of the people in those geographical areas, the history of the people, their art, architecture, religion, and other elements that helped shape their way of life (Audiences London, 2010). In 1985, World Tourism Organization (UNWTO) defined Cultural tourism as movements of persons for essentially cultural motivations such as study tours, performing arts and cultural tours, travel to festivals and other cultural events, visits to sites and monuments, travel to study nature, folklore or art, and pilgrimages. Festivals are parts of numerous Cultural tourism assets that Nigeria can boost of. Examples of such festivals include Osun Osogbo festival, Argungu fishing festival, Calabar Carnival, New Yam festivals, Eyo festival, Lagos Carnival, Ofala festival, Carnifir festival, Ojude Oba festival, Sango festival, Shao - Awon Mass Wedding festival among others. All these festivals are colourful and interesting. However, while some of these festivals are similar in one way or the other, many are also different and unique from one another.

\section{Literature Review}

Globally, the importance of heritages to countries and even in developing nations like Nigeria cannot be over - emphasized. Nigeria is a country located in Eastern part of West Africa (Aremu, 2008). It is the most populated multiethnic and multilingual country in Africa with over 25 o ethnic groups.
Nigeria is endowed with about 29 game reserves, 1129 forest reserves, 4 game sanctuaries, 2 strict nature reserves and 8 national parks (Mathaias and David, 2014). Nigeria is distinguished in subSaharan Africa because of her rich manifestations of vast cultural heritages of the past (Sowunmi, 2008). Eluyemi (2002) defined heritage preservation as the promotion of cultural property whether of concrete or non - concrete nature, past or present, written, or unwritten. However, this preservation is arguably threatened by human activities, natural forces, biological and chemical agents among others (Ogundele, 2014; Okpolo, 2011). According to Bakare (2010), the trend of cultural tourism in Nigeria is being hampered by certain unscrupulous factors, looting, restrictions, lack of befitting accommodation in the host circuit, lack of good access roads, poor infrastructure in the host communities and lack of proper orientation and publicity by the affected government tiers. Among the reasons for these hindrances is poverty, high level of ignorance and to cork it all, lack of appreciation of indigenous art among Nigerian. However, there is no better way you can get the feel of Nigeria's rich cultural heritage than experiencing the colourful celebration of the various cultural festivals. One of the unique Nigerian cultural heritage is Awon Mass Wedding Festival which takes place in Shao, Kwara State, Nigeria annually.

The history of the people of Shao (one of the major towns in Kwara State) predated the founding of Ilorin (the present headquarters of Kwara State). Shao people came from the Old Oyo Empire. The traditional head of the town, called Ohoro, is a direct descendant of Alafin of Oyo. Shao is located in Moro Local Government area of Kwara State, Nigeria, on an elevation of 269 meters above the sea level. Its coordinates are $8^{\circ} 34^{\prime} 60^{\prime \prime} \mathrm{N}$ and $4^{\circ} 34^{\prime} 0^{\prime \prime}$ E in DMS (Degrees Minutes Seconds) or 8.58333 and 4.56667 in decimal degrees (Joe, 2014). The people of Shao are majorly farmers, herders, and traders. Historically, there was a one breasted goddess who appeared to the people of the ancient community of Shao precisely during the reign of the first monarch of the community (Ibitowa, 2015). Whatever is regarded as the authentic account of the historical origin of Awon Mass Wedding Festival must have been sourced from oral tradition which obtains in a community like Shao where written tradition was introduced to it via contact with western education (Kehinde, 
2013). But even then, the historical account of the festival has since been reduced to writing by individuals as well as government. According to Oke (1992), in Shao, the institution of marriage is given a pride of place in the culture of the people. Giving out a daughter in marriage in Shao is not the affair of the family alone, it is the responsibility of the entire community. The festival came into being through the contact between an ancient Chief in Shao and the mysterious woman. The chief who was a hunter discovered a small stream where he always visited to drink water during his hunting expeditions. On one of such hunting adventures, he had an encounter with this strange woman who appeared to him mysteriously and claimed the ownership of the stream. She identified herself as Awon and requested the hunter to lead her to the community where she was received by the first traditional head of the community and his other chiefs. She was kept in the custody of a man for nine 9 days before departing the town. The man she stayed with is today, the chief priest of Awon Festival. In her valedictory speech, Awon instructed the king and his chiefs to set a day aside annually to commemorate her visit by giving all marriageable girls out in marriage. She equally told them that the community should expect prosperity so far, they take to her instruction. Awon had hardly finished her speech when she fell down and vanished into the air and immediately, water started gushing out and flow from the spot. The water flowed to join the erstwhile stream discovered by the hunter to become a big river referred to as Awon River till the present day. Awon Mass Wedding Festival is celebrated in stages as a number of activities are orchestrated to usher in the annual mass wedding fiesta (Kwara State Government, 2007). The events are as follows; date fixing (between August and September annually), gathering of firewood by family members of the intending bridegrooms, carrying of two bundles of firewood, two big baskets of yams and a big cock by the women from the bridegroom's family to bride's family, wedding eve (bride's visitation to relatives), and the main wedding day. Activities of the main wedding day include; display of bride's earthenware (pots, plates, cooking utensils etc., and bridal slow procession to market square with unique hair do and accessories such as; umbrella, jewelries, bangles, beads), singing the ancestral praise of the monarch, Awon dance (a traditional dance by every woman in the town which takes place two months after the festival and involves baking, eating, and sharing of bean cake), hunters' display of acrobatics, and finally, blessing of the brides by the monarch.

\section{Figure 1}

Cross Section of the brides during the 2018 edition of the festival (picture taken by the researcher)

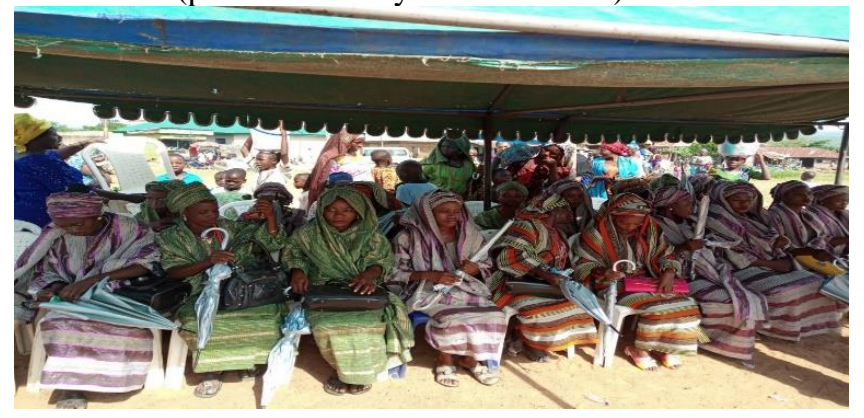

Figure 2

Some of the maidens during procession to the venue of the festival (picture taken by the researcher)

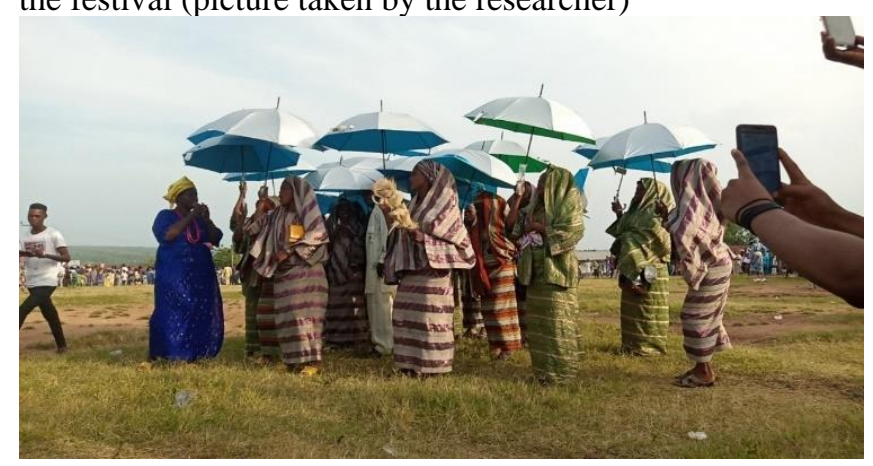

\section{Conceptual background and hypotheses framework}

\subsection{Statement of the Problem}

Globalization effects are not optional for developing countries. In Nigeria, its effects are compelling and imperative. Globalization trend has also had an adverse effect on the socio-cultural development of Nigeria. The social aspect is that globalization has deeply influenced the social structure of different societies to the extent that any particular society following their style of living without being much influenced by the western culture is now seen as uncivilized. If strategies are not designed to reverse the trend, the resultant effect of globalization will make us become people without any historical past. Considering the effects of globalization/civilization on our culture in Nigeria, it is worthy of researching into any surviving cultural heritage with the goal of sustaining such heritage and its legacies. This study 
was therefore designed to determine the perception of Awon Mass Wedding Festival (one of Nigeria's age - long traditions in Kwara State) by the contemporary Shao community in Kwara State, Nigeria.

\subsection{Objectives of the Study}

The main objective of this study was to determine contemporary Shao community's perception of Awon Mass Wedding Festival in Kwara State, Nigeria. The specific objectives were to:

- determine socio-economic characteristics of respondents.

- identify factors influencing maidens' participation in the festival.

- identify problems militating against the development of the festival.

\subsection{Conceptual framework}

According to Dopamu, (2004), festival will continue to be celebrated and continue to express man's relationship with the supernatural and to their fellow human beings. Festivals in Nigeria can provide a serious of social and economic boost to Nigeria, bringing about social cohesion, youth empowerment, community engagement, talent development, tourism spend, taxable revenues and inward investment. There are festivals to celebrate traditional, religious or cultural milestones or practices. Festivals can create unique value for domestic and international tourists. They are primarily organized by local communities and are funded by government, wealthy community members or corporates. Depending on the size and accessibility of the festival, they can be a big attraction for domestic and international tourism. Festival organizers, stakeholders and general members of the public are extremely positive about festivals, as a vehicle for social cohesion, artistic development, economic enrichment and/or as a viable business. Yemisi and Bertram (2016) established that opportunities for festivals to thrive in Nigeria are embedded in the abundance of highquality artistic talent in Nigeria, the size of the population available as potential festival goers and the already existing culture of celebration and ceremony in Nigeria. The main weaknesses as identified are based around skills deficit of operational and technical events staff and a major threat is the limited understanding of the benefits of festivals by sponsors, government and local businesses. However, there is no gainsaying the fact that modern forces of social change, precisely, western science, technology education and religion are today undermining the effective practice of the indigenous religion (where most festivals are embedded) of most African communities (Wotogbe-Weneka, (2006). Also, examining the contemporary perception of the festivals by the people which may be influenced by socioeconomic parameters such as age, education, religion, cosmopolitanism, marital status, income among others is very germane in determining the extent of changes in traditional festivals attributable to social change.

\subsection{Hypotheses of the Study}

HI: There is no significant relationship between the socio-economic characteristics of the respondents and perception of Awon festival.

$\mathrm{H} 2$ : There is no significant relationship between the respondents' level of cosmopolitanism and perception of Awon festival.

H3. There is no significant difference between male and female perception of the Awon festival.

\subsection{Study Area}

Shao is located in Moro Local Government Area of Kwara State, Nigeria. Its geographical coordinates are $8^{\circ} 35^{\prime} 0^{\prime \prime}$ North, $4^{\circ} 34^{\prime} 0^{\prime \prime}$ East. The people of Shao are basically farmers, traders and herders.

\section{Figure 3:}

The black spot in the middle of the map represents the location of the study area (Shao) within the entire map of Kwara State, Nigeria.
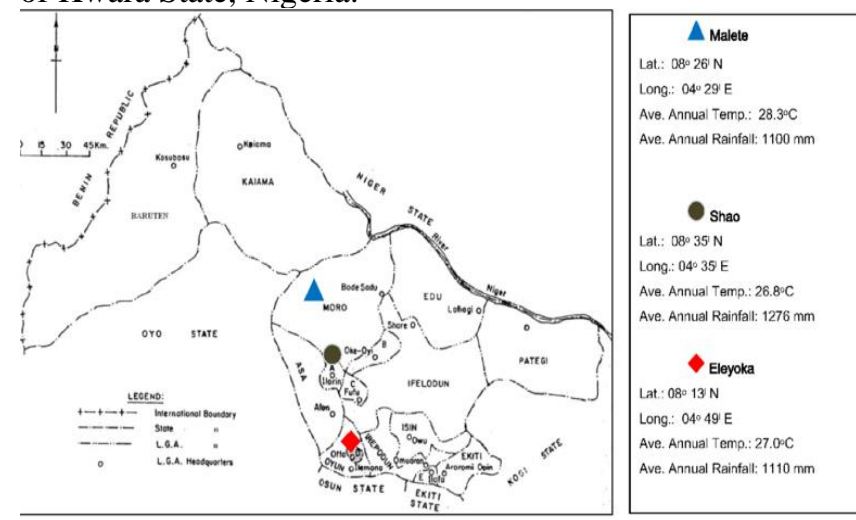

\section{Methodology}

Out of the twenty-five maidens who got married during the 2018 edition of the festival, twenty accepted to participate in this study, hence, they were selected purposively. Questionnaires were administered for one hundred and ten members of 
the community who were selected by simple random sampling technique; however, 107 questionnaires were retrieved for analysis. Data were collected between $15^{\text {th }}$ of October 2018 and $15^{\text {th }}$ of November 2018.

\section{Results and Discussion}

\section{Table 1}

Socio - Economic Characteristics of Respondents $\mathrm{n}=$ 107

\begin{tabular}{|c|c|c|}
\hline Characteristics & Frequency & Percentage \\
\hline \multicolumn{3}{|l|}{ Gender } \\
\hline Male & 42 & 39.3 \\
\hline Female & 65 & 60.7 \\
\hline \multicolumn{3}{|l|}{ Age (years) } \\
\hline Less than 20 & 29 & 27.1 \\
\hline $21-30$ & 50 & 46.7 \\
\hline $31-40$ & 13 & 12.1 \\
\hline $41-50$ & 07 & 6.5 \\
\hline 51 and above & 08 & 7.5 \\
\hline \multicolumn{3}{|l|}{ Religion } \\
\hline Islam & 46 & 43.0 \\
\hline Christianity & 46 & 43.0 \\
\hline Traditional & 14 & 13.1 \\
\hline Others & 01 & 0.9 \\
\hline \multicolumn{3}{|l|}{ Tribe } \\
\hline Yoruba & 94 & 87.9 \\
\hline Hausa & 01 & 0.9 \\
\hline Igbo & 06 & 5.6 \\
\hline Fulani & 06 & 5.6 \\
\hline \multicolumn{3}{|l|}{ Level of education } \\
\hline No formal education & 03 & 2.8 \\
\hline Primary & 12 & 11.2 \\
\hline Secondary & 34 & 31.8 \\
\hline Tertiary & 58 & 54.2 \\
\hline \multicolumn{3}{|l|}{ Level of income } \\
\hline Below $¥ 50,000$ & 83 & 77.6 \\
\hline$\$ 50,000-\$ 100,000$ & 18 & 16.8 \\
\hline $\mathrm{N} 101,000-\mathrm{N} 150,000$ & 01 & 0.9 \\
\hline
\end{tabular}

\subsection{Socio-economic characteristics of respondents}

Data in Table 1 shows that more female (60.7\%) participated in the study than the male counterpart $(39.3 \%)$. Majority of the respondents $(73.8 \%)$ were within the age range of 21 and 40 years. While equal number of Muslims (43\%) and Christians (43\%) participated in the study, $13.1 \%$ were traditionalists. Majority (87.9\%) of the respondents were of Yoruba tribe of Nigeria. Above average (54.2\%) attended higher institutions of learning while $31.8 \%$ had secondary education, hence not fewer than $86 \%$ of the respondents had minimum of secondary education. Majority of the

respondents (77.6\%) were low income earners, earning $\$ 50,000$ and below. The above data shows that the respondents were of varied personal status.

\subsection{Socio - Economic Characteristics of Maidens}

From table 2 below showing the socio-economic characteristics of the maidens, while $40 \%$ of the maidens were within the age range of 25 and 29 years, majority (60\%) were 24 years and below, thus, it could be deduced that the festival encouraged early marriage. Also, significant number of maidens from the two main religions (60\% Muslims and 40\% Christians) participated in the festival, hence, it could be inferred that all faiths subscribed to the festival. Majority of the maidens $(80 \%)$ had secondary education while a few $(20 \%)$ had tertiary education, however, all the maidens were low income earners (\#50,000 and below). All the maidens worked in the informal sector; artisans $(60 \%)$, traders $(30 \%)$ and farmers $(10 \%)$, and all of them were also members of different social organizations occupying one position or the other. This implies that maidens who participate in social organizations and who are not highly educated (not working in formal sector) are the ones that usually participate in Awon festival.

Table 2

Distribution of maidens by socio - economic characteristics

\begin{tabular}{|c|c|c|}
\hline Characteristics & Frequency & Percentage \\
\hline \multicolumn{3}{|l|}{ Age (years) } \\
\hline Less than 20 & 04 & 20.0 \\
\hline $20-24$ & 08 & 40.0 \\
\hline $25-29$ & 08 & 40.0 \\
\hline \multicolumn{3}{|l|}{ Religion } \\
\hline Islam & 12 & 60.0 \\
\hline Christianity & 08 & 40.0 \\
\hline Traditional & 00 & 00.0 \\
\hline \multicolumn{3}{|l|}{ Tribe } \\
\hline Yoruba & 20 & 100.0 \\
\hline Hausa & 00 & 00.0 \\
\hline Igbo & 00 & 00.0 \\
\hline Fulani & 20 & 100.0 \\
\hline \multicolumn{3}{|l|}{ Level of education } \\
\hline Primary & 00 & 00.0 \\
\hline Secondary & 16 & 80.0 \\
\hline Tertiary & 04 & 20.0 \\
\hline \multicolumn{3}{|l|}{ Level of income } \\
\hline Below $¥ 50,000$ & 20 & 100.0 \\
\hline$\$ 50,000-\$ 100,000$ & 00 & 00.0 \\
\hline$\$ 101,000-\$ 150,000$ & 00 & 00.0 \\
\hline
\end{tabular}




\section{Figure 4}

Bar chart showing factors influencing maidens' participation in the festivalSource: Field Survey 2018

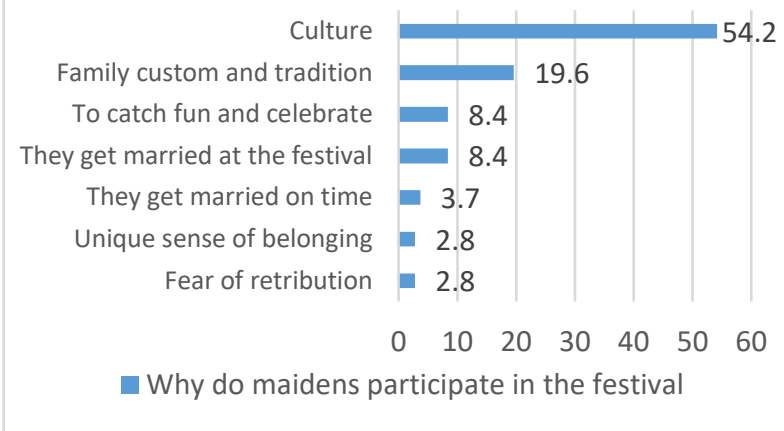

5.3 Factors Influencing Maidens' Participation in Shao Awon Festival

Data in Figure 1 revealed reasons for maidens' participation in the mass wedding festival. The two leading significant reasons were interrelated, these are culture $(54.2 \%)$ and family custom and tradition (19.6\%). According to many of the respondents, the festival is the culture of the community which must be respected. Many also reported that the festival is their individual family custom and tradition which must be obeyed and respected, hence, they have no excuse not to participate in it. Other less important reasons for participating in the festival were; fun and celebration $(8.4 \%)$ i.e. because of the celebration and festivity involved, marriage purpose $(8.4 \%)$ i.e. to get married during the festival, getting married quick $(3.7 \%)$ i.e. to ensure that the maidens were not tempted to get deflowered since they had strived to preserve their chastity, unique sense of belonging $(2.8 \%)$ i.e. some maidens felt they just had to identify with their community, and fear of retribution $(2.8 \%)$ i.e. some maidens do participate in the festival because they were afraid of negative consequences of not conforming to the community marriage system. However, during key informant interview with the King (Ohoro of Shao) and the Chief Priest (Baba Alawon), they said fear of retribution should not be exercised by any maiden of Shao because it is not compulsory for all maidens to participate in the festival, the festival is for whoever is interested and that, it must be observed every year in other to fulfil the part the community had with the goddess, Awon.

\section{Table 3}

Distribution of respondents by factors discouraging maidens' participation and ways of improving conduct of the festival

\begin{tabular}{|l|c|c|}
\hline \multicolumn{1}{|c|}{ Characteristics } & Frequency & Percentage \\
\hline $\begin{array}{l}\text { Factors discouraging maidens from } \\
\text { participating in the festival }\end{array}$ \\
\hline Civilization & 39 & 36.4 \\
\hline Religion & 19 & 17.7 \\
\hline Lack of interest & 06 & 5.6 \\
\hline Emigration & 02 & 1.9 \\
\hline Education level & 04 & 3.7 \\
\hline $\begin{array}{l}\text { Erroneous belief } \\
\text { about implication }\end{array}$ & 03 & 2.8 \\
\hline Ways of improving the festival & \\
\hline $\begin{array}{l}\text { Awareness and } \\
\text { publicity }\end{array}$ & 46 & 43.0 \\
\hline $\begin{array}{l}\text { Sponsorship by } \\
\text { government }\end{array}$ & 41 & 38.3 \\
\hline Encourage participate & 16 & 14.9 \\
\hline $\begin{array}{l}\text { More relaxation } \\
\text { activities included }\end{array}$ & 04 & 3.7 \\
\hline
\end{tabular}

5.4 Factors Discouraging Maidens' Participation and Ways of Improving Conduct of the Festival

Data in Table 5 shows that many respondents $(67.3 \%)$ were of the opinion that not all the maidens in the community do participate in the festival. This revealed that the festival is no longer generally accepted by the whole community. The identified factors discouraging participation in order of importance include the following: civilization $(36.4 \%)$, religion $(17.7 \%)$, lack of interest (5.6\%), educational level (3.7\%), erroneous belief about implications of participation in the festival (2.8\%), and emigration (1.9\%). These findings showed the impact of civilization and religion on our culture. It also revealed that it is important for Africans to seek information on any aspect of their culture they were not clear of before taking decision on them. Ways of improving the conduct of the festival identified in this study were increasing awareness and publicity (43\%), securing sponsorship from government, NGOs, corporate bodies, and international organizations $(38.3 \%)$, encouraging people to participate $(14.9 \%)$ and including more relaxation activities in the festival $(3.7 \%)$. In other to encourage more people to participate, activities such as; football match competition, raffle draw, product exhibition and product sales at discounted prices, and performances by popular actors, actresses and musicians could be explore. However, in other to 
encourage more maidens to participate, the community need to devise strategies to create more awareness, re-orientate and educate, most especially stressing the fact that nothing spiritual is attached to the festival.

\section{Table 4}

Perception of Awon Mass Wedding Festival

\begin{tabular}{|c|c|c|c|c|c|c|}
\hline STATEMENT & $\begin{array}{c}\text { SA } \\
\text { Freq }(\%)\end{array}$ & $\begin{array}{c}\text { A } \\
\text { Freq }(\%)\end{array}$ & $\begin{array}{c}\mathrm{U} \\
\text { Freq }(\%)\end{array}$ & $\begin{array}{c}\text { D } \\
\text { Freq }(\%)\end{array}$ & $\begin{array}{c}\text { SD } \\
\text { Freq }(\%)\end{array}$ & $\begin{array}{l}\text { Mean } \pm \\
\text { SD }\end{array}$ \\
\hline It is our unique cultural heritage & $79(73.8 \%)$ & $24(22.4 \%)$ & $02(1.9 \%)$ & $01(0.9 \%)$ & $01(0.9 \%)$ & $4.67 \pm 0.66$ \\
\hline $\begin{array}{l}\text { It fosters unity among members of the } \\
\text { community }\end{array}$ & $62(57.9 \%)$ & $37(34.6 \%)$ & $05(4.7 \%)$ & $02(1.9 \%)$ & $01(0.9 \%)$ & $4.47 \pm 0.76$ \\
\hline $\begin{array}{l}\text { Opportunity for indigenes to come home } \\
\text { and rejoice with those at home }\end{array}$ & $65(60.7 \%)$ & $32(29.9 \%)$ & $05(4.7 \%)$ & $03(2.8 \%)$ & $02(1.9 \%)$ & $4.45 \pm 0.86$ \\
\hline $\begin{array}{l}\text { It encourages Shao girls to maintain their } \\
\text { chastity until they are ready for marriage }\end{array}$ & $61(57.0 \%)$ & $35(32.7 \%)$ & $05(4.7 \%)$ & $06(5.6 \%)$ & $00(0.0 \%)$ & $4.41 \pm 0.82$ \\
\hline $\begin{array}{l}\text { It supports parents in inculcating morals } \\
\text { on their female children }\end{array}$ & $63(58.9 \%)$ & $32(29.9 \%)$ & $10(9.3 \%)$ & $02(1.9 \%)$ & $00(0.0 \%)$ & $4.46 \pm 0.74$ \\
\hline It makes our town popular in the country & $46(43.0 \%)$ & $40(37.4 \%)$ & $11(10.3 \%)$ & $07(6.5 \%)$ & $03(2.8 \%)$ & $4.11 \pm 1.02$ \\
\hline It is against my religious belief & $11(10.3 \%)$ & $15(14.0 \%)$ & $23(21.5 \%)$ & $28(26.2 \%)$ & $30(28.0 \%)$ & $2.52 \pm 1.31$ \\
\hline It is an uncivilized culture & $07(6.5 \%)$ & $27(25.2 \%)$ & $18(16.8 \%)$ & $24(22.4 \%)$ & $31(29.0 \%)$ & $2.58 \pm 1.32$ \\
\hline $\begin{array}{l}\text { It encourages maidens to get married on } \\
\text { time }\end{array}$ & $31(29.0 \%)$ & $44(41.1 \%)$ & $15(14.0 \%)$ & $09(8.4 \%)$ & $08(7.5 \%)$ & $3.76 \pm 1.18$ \\
\hline $\begin{array}{l}\text { It is not a good way of conducting } \\
\text { marriage ceremony }\end{array}$ & 09 (8.4\%) & $18(16.8 \%)$ & $18(16.8 \%)$ & $24(22.4 \%)$ & $38(35.5 \%)$ & $2.40 \pm 1.34$ \\
\hline $\begin{array}{l}\text { It is a culture practiced only by the less } \\
\text { privileged }\end{array}$ & $08(7.5 \%)$ & $13(12.1 \%)$ & $18(16.8 \%)$ & $28(26.2 \%)$ & $40(37.4 \%)$ & $2.26 \pm 1.28$ \\
\hline Mean \pm S.D $=3.6448 \pm 1.0272$ & & & & & & \\
\hline
\end{tabular}

\subsection{Residents' Perception of Awon Mass Wedding Festival}

From table 4 above, a mean score of 2.5 and above shows agreement and a mean score of 2.49 and below shows disagreement. Therefore, majority (4.67) agreed that Awon mass wedding festival is their unique cultural heritage, majority (4.47) agreed that it fosters unity among members of the communities, majority (4.45) agreed that it provides opportunities for indigenes in diaspora to come home and rejoice with those at home, majority (4.41) agreed that it encourages girls to maintain their chastity until marriage, majority (4.46) agreed that it supports the parents in inculcating morals in their female children, majority (4.41) agreed that it makes their town popular, a little above average (2.52) agreed that the festival is against their religion, majority (2.58) agreed that it is an uncivilized culture, majority (3.76) agreed that it encourages maidens to get married on time, majority (2.60) agreed that it is a good way of conducting wedding ceremony and majority (2.74) also agreed that it is not a culture practiced by only the less privilege. These findings showed that majority of the community members still have a positive perception of the festival.

\section{Table 5}

Correlation matrix showing the relationship between the socio-economic characteristics of the respondents and perception of Awon festival.

\begin{tabular}{|l|c|c|c|}
\hline \multicolumn{1}{|c|}{ Variables } & $\begin{array}{c}\text { Correlation } \\
\text { coefficient }(\mathbf{r})\end{array}$ & $\begin{array}{c}\text { Coefficient of } \\
\text { determination }\left(\mathbf{r}^{2}\right)\end{array}$ & $\begin{array}{c}\text { Level of } \\
\text { Significance (p) }\end{array}$ \\
\hline Age & 0.122 & 0.0149 & 0.209 \\
\hline Education & $-0.194^{*}$ & 0.0376 & 0.045 \\
\hline $\begin{array}{l}\text { Level of } \\
\text { Income }\end{array}$ & 0.113 & 0.0128 & 0.246 \\
\hline $\begin{array}{l}\text { Membership } \\
\text { of Social } \\
\text { organization }\end{array}$ & $0.304^{*}$ & 0.0924 & 0.001 \\
\hline
\end{tabular}

The above table reveals a negative and significant relationship between education $\left(\mathrm{r}=-0.194^{*}, \mathrm{p}=\right.$ 0.045) and perception of Awon festival. This implies that as the level of education of the respondents improves, their perception of the festival becomes poorer. Also, the table shows a 
positive and significant relationship between membership of social organizations $\left(r=0.304^{*}, p\right.$ $=0.001)$ and perception of Awon festival. This implies that respondents have better perception of the festival with increased involvement in social organization.

\section{Table 6}

Correlation matrix showing the relationship between respondents' level of cosmopolitanism and perception of Awon festival.

\begin{tabular}{|c|c|c|c|}
\hline Variables & $\begin{array}{c}\text { Correlation } \\
\text { coefficient } \\
(\mathbf{r})\end{array}$ & $\begin{array}{c}\text { Coefficient of } \\
\text { determination } \\
\left(\mathbf{r}^{\mathbf{2}}\right)\end{array}$ & $\begin{array}{c}\text { Level of } \\
\text { Significance } \\
(\mathbf{p})\end{array}$ \\
\hline Cosmopolitanism & 0.119 & 0.0142 & 0.222 \\
\hline
\end{tabular}

The data in table 9 shows that there is no significant relationship between respondents' level of cosmopolitanism $(r=0.119, \mathrm{p}=0.222)$ and perception of Awon festival. This implies that the level of cosmopolitanism of the respondents does not affect their perception of the festival.

\section{Conclusion}

This study established that the perception of Awon festival by the present Shao community had been grossly influenced by Islam and Christianity. The most elderly of the maidens who participated in the 2018 edition was 24 years old, this implies that the festival encourages girls to protect their chastity and motivate them for early marriage. Contemporarily, not all maidens of the community subscribe to the festival unlike in the past. The maidens who participate in the festival nowadays are of low socio-economic characteristics, which implies that people of higher socio-economic status do not subscribe to the festival. The most important factors influencing maidens' participation in the festival was because the festival is a well-respected culture of their individual family and that of the community as a whole, another important influencing factor worthy of mention was the maidens' fear of retribution. Factors discouraging maidens' participation identified were civilization, religion, absence of interest, educational level, and erroneous belief about implications of participation in the festival. The study also established the following strategies to further develop the festival; increasing awareness and publicity, securing sponsorship, and encouraging more people to participate. Many of the respondents concurred on the numerous benefits of the festival, however, they disagreed that it is not against their religious belief and that it is not an uncivilized culture. The study established that the higher the level of education of the residents, the poorer the perception of the festival and that residents who participate in the social organizations have better perception of the festival.

\section{Recommendations}

Following the conclusions of this study, the following recommendations were suggested;

- Members of the community should be reorientated about the festival, more particularly to clear their doubt on the fear of retribution for non-participating maidens. It is very important to emphasize to their hearing that participation in the festival by maidens is not compulsory, however, it is a unique culture which the community should strive to sustain, and which can bring many benefits such as; seasonal job opportunities, infrastructural development, revenue generation etc. if well promoted.

- This study established that majority of the members of the community perceived the festival as an uncivilized culture. This is one of our major problems in Africa, preference of foreign culture to local culture. People need to be educated that no culture is better or superior to the other, rather, the uniqueness of Awon festival should be highly cherished, embraced, and explore for sustainable tourism development and its associated benefits.

- Efforts should be made to sustain the festival's ability to encourage maidens to keep their chastity until marriage. This is one of the core values of African marriage system which is no longer popular.

- To encourage more participation by the host community, activities such as, football competition, raffle draw, products' exhibition, product sales at discounted prices, and performances by celebrities/entertainers/musicians could be consider.

- The packaging of the festival needs to be revisited by the Local Organizing Committee (LOC). Tourism Journalists and Tour Operators nationally and internationally should be involved in the packaging, publicity and marketing of the festival.

It was observed that majority of the maidens who participated in the festival were of low social status 
i.e. low income earner, low level of education etc. Hence, encouraging and getting maidens of high social status to participate in the festival will further stimulate the interest of the festival among the entire maidens of the community regardless of social status occupied.

It was observed that two of the participants were already married before coming back to participate in the festival. This should be discouraged so that the originality of the festival can be maintained.

\section{References}

Aremu, D.A. (2008). Preservation of Land, Culture and Wildlife for the Development of Ecotourism in Africa, Spectrum Books Ltd, Ibadan, Nigeria.

Audiences London (2010). How to Define and Approach Cultural Tourism, Cultural Tourism Resources, retrieved from www.audienceslondon.org accessed on 19/6/2018.

Bakare, K. O. (2010). Tradition and Art Appreciation: A

Boost to Cultural Tourism in Nigeria. African Research Review, 4 (4), 506 - 520.

Bello, S. (2001). African's Culture: Paradigm for African Technological Development, retrieved from www.africult/develop/html (access 20/6/2018)

Chibuzor, A. (2018). Traditional Festivals in Nigeria: Their Importance and What they are all about, retrieved from www.nigerianfact.com and accessed on 30/11/2019.

Dopamu P. A. (2004). Traditional Festivals. In N. S. Lawal et. al. (Eds.). Understanding Yorùbá Life and Culture. Asmara: Africa World Press.

Eluyemi, O. (2002). The Preservation of Nigerian Cultural Heritage: Challenges and Prospects, 4thBasseyWaiAndah Memorial Lecture, Textflow Ltd, Ibadan, Nigeria.

Hat Tours (2012). Festivals, retrieved from www.hattours.comand accessed on 19/6/2018.

Ibitowa, S. (2015). Awon Mass Wedding Festival in Shao, Kwara State, Nigeria, retrieved from www.infoguidenigeria.com accessed on 20/04/2019.

Joe, O. O. (2014). We are Children of Oduduwa, retrieved from www.ilorininfo.com accessed on 23/4/2018.
Kehinde, R. A. (2013). Exploring the Aesthetics of Awon Mass Wedding Festival for Tourism Development and Globalization. Journal of Arts, Humanities and Diplomacy, 3(2), 36 - 48.

Kwara State Government (2007). Historical Perspective of Shao Awonga Festival: Awonga Mass Marriage. A Publication of the Kwara State Government. Office of the Special Assistant to the Executive Governor on Tourism and Kwara State Tourism Board.

Mathaias, A. B. and David, M. (2014). Irumgbede: An Idigenous Educational Institution. In Ezeweke, E. O. (Ed.) African Traditional Religion Philosophy and Sustainable Development. Jos, Fab Anieh Nigeria. Ltd.

Montserrat, C. (2007). The Meaning of Cultural Festival. International Journal of Cultural Policy, $13(1), 103-122$.

Ogundele, S. O. (2014). Understanding Contemporary Archaeology. Ibadan, John Archers Publishers Limited.

Oke, W. (1996). My People, their Tradition; Custom and Culture, Matami and Sons Co. Ltd., Ilorin, Kwara State, Nigeria.

Okpoko, A. I. (2011). Fundamentals of museum practice. Nsukka, University of Nigeria Press Limited.

Sowunmi, M. A. (2008). Tourism and security: Facing the Challenges. In D.A. Aremu, (Ed.) Preservation of Land, Culture \& Wildlife for the Development of Ecotourism in Africa. Ibadan, Spectrum Books Limited.

World Tourism Organization (1985). The State's Role in Protecting and Promoting Culture as a Factor for Development and the Proper Use and Exploitation of the National Cultural Heritage of Sites and Monument for Tourism, WTO, Madrid, Spain.

Wotogbe-Weneka, W. O. (2006). Worship Ethics in an African Religious Shrine of a Possession Cult among the Ikwerre of Upper Niger Delta. In M. T. Yahya et al (eds.) Issues in the Practice of Religion in Nigeria. Jos: Nigerian Association for the Study of Religious (NASR).

Yemisi, M. and Bertram, L. (2016). Understanding the Festival Scene in Nigeria, Hatch Africa Solutions Ltd, British Council, UK 